\title{
Analysis on the Problems and Countermeasures of Innovation and Entrepreneurship in Vocational Colleges Against the Background of "Internet Plus"
}

\author{
Ge Gao \\ Jiyuan Vocational and Technical College \\ Jiyuan, China
}

\begin{abstract}
The arrival of the information age marks that China's social development has entered a new historical stage. At this stage, the emergence and development of "Internet Plus" has provided a broader platform for China's mass entrepreneurship. As a major driving force for "mass entrepreneurship", college students face both more entrepreneurial paths and platforms and greater challenges in "Internet Plus" era. The "mass entrepreneurship and innovation" strategy and the advent of the Internet era put China's current entrepreneurs in a good position both in policy and on the platform. It's obvious that college students, major force for entrepreneurship, enjoy advantages in entrepreneurial ideas and innovation and entrepreneurship [1]. As an important place for cultivating vocational and technical talents, vocational colleges play a very active role in the era of "nation-wide entrepreneurship". In "Internet Plus" era, only by correctly guiding students, making scientific teaching plans and carrying out corresponding innovation and entrepreneurship education work in combination with "Internet Plus", can the overall level of college students' selfemployment in vocational schools be improved continuously fundamentally.
\end{abstract}

Keywords-"Internet Plus"; vocational colleges; innovation and entrepreneurship; market; policy; college students

\section{INTRODUCTION}

It is an issue worthy of attention in the current stage of vocational college education to correctly guide college students' innovation and entrepreneurship and continuously improve their ability of innovation and entrepreneurship. Against the current environment of innovation and entrepreneurship, entrepreneurial channels and platforms are more abundant. However, there also exist big difficulties and huge challenges. This paper analyzes the existing problems and countermeasures of vocational colleges' innovation and entrepreneurship in the "Internet + " environment.

\section{THE IMPACT OF THE "INTERNET PLUS" ERA ON CONTEMPORARY COLLEGE STUDENTS}

First of all, with the advent of the "Internet + " era, students' learning styles and learning choices are more diversified. For vocational college students, they have more ways to acquire knowledge and break the shackles of time and space [3]. In addition, Internet technology also provides a broader source of knowledge for contemporary vocational college students, which is of great significance for improving students' learning ability and innovation ability.

Secondly, the arrival of the "Internet + " era has changed the social habits of contemporary college students to a large extent. In the era of "Internet $+"$, college students can communicate and exchange with people in any part of the world through the Internet social platform. Such communication can not only break the limitations of time and space, but also enrich the channels for students to obtain information, which has positive impact on promoting the innovation and entrepreneurship ability of vocational college students.

Finally, the arrival of the "Internet + " era has also changed the consumption concept and lifestyle of college students to some extent [4]. "Internet +" mainly combines the application of modern information technology with traditional industries, and builds corresponding Internet platforms, such as e-commerce platforms. The emergence of e-commerce platforms and the popularity of smart terminals have made contemporary college students prefer ecommerce platforms for consumption, which has a great impact on college students' consumption concepts and lifestyles. The survey found that more than $85 \%$ of vocational college students are spending through the Internet platform.

\section{SWOT ANALYSIS OF COLLEGE STUDENTS'}

INNOVATION AND ENTREPRENEURSHIP AGAINST THE BACKGROUND OF "INTERNET PLUS"

\section{A. Analysis of the Advantages of Innovation and}

Entrepreneurship of Vocational College Students

Against the Background of "Internet Plus"

In the context of "Internet + ", the advantages of college students in innovation and entrepreneurship mainly include two aspects. First of all, there are a large number of vocational colleges in China. According to incomplete statistics, there are 12,300 vocational colleges in China, and the number of enrolled students per year is about 9,307,800. Such a large number of colleges and universities as well as the number of personnel training provide strong talent support for the implementation of the policy of "mass 
entrepreneurship and innovation" in China [5]. Secondly, the distribution of vocational colleges in China is relatively balanced at present. Both the developed areas in the eastern coastal areas and the inland areas in the northwest have vocational institutions. Coupled with the influence of regional policies, many fresh graduates are interested in starting their own businesses locally, which has a very positive impact on the balanced development of China's national economy. Finally, training goals for vocational college students are also very helpful to help college students start their own businesses. Generally speaking, in the process of talent cultivation in vocational colleges, the main talent training mode is "professional theory + vocational skill practice" [6]. Therefore, compared with talents from other universities, vocational college students have more obvious advantages in innovation and entrepreneurship.

\section{B. Analysis of the Disadvantages of College Students' Innovation and Entrepreneurship Against the Background of "Internet Plus"}

In the context of "Internet + ", although the innovation of college students has great advantages in terms of talent quantity and distribution scope, it also has obvious disadvantages in terms of innovation and entrepreneurship compared with the talents of ordinary undergraduate colleges.

First, the overall level of the ideological concepts and innovation consciousness of vocational college students is not particularly high. For college students in vocational colleges, the education and study are dominated by vocational education, which can improve students' professional skills to a large extent. However, in the actual teaching process, teachers often pay less attention to the cultivation of students' innovative consciousness [7], which leads to the fact that many vocational college students have strong professional skills and qualities, but weak innovation consciousness. In addition, there is a great lag in the ideology of many college students. Under the combined effects of many factors, the disadvantages of vocational college students in innovation and entrepreneurship are becoming more and more obvious.

Second, China's industrial structure development is not particularly balanced. The imbalance of industrial structure is mainly reflected in two aspects: on the one hand, the imbalance of industrial development between the southeast coast and the inland northwest; on the other hand, the imbalance of industrial development between rural and urban areas. At present, China's vocational colleges are mostly distributed in second - and third-tier cities and remote areas of the city. The study found that industries in the region where vocational colleges are located are mostly the primary industry and the secondary industry. [8] Thus In the process of innovation and entrepreneurship, college students in vocational colleges have great limitations in the selection of entrepreneurial projects and the utilization of resources. In addition, in many areas of China, due to the late start of its ecommerce industry, many college students with innovative and entrepreneurial skills often face many difficulties in the process of starting a business. For example, local people do not recognize the new business model, and entrepreneurial projects are greatly affected by traditional industries. The imbalance of industrial structure has also become one of the disadvantages of professional college students in the process of innovation and entrepreneurship development [9].

Third, the late start of e-commerce. For most of China, although Internet technology has been applied to specific production life in recent years, and e-commerce has also been greatly developed, however, its late start makes most the e-commerce in most parts of China still in the infant stage. As a result, many college students face great difficulty in starting a business successfully against the background of "Internet +" because of immature market environment and the influence of large-scale e-commerce platforms. The lack of mature market experience in the region of college students makes it more challenging for them to start own business against the background of "Internet + ".

\section{Analysis of the Opportunities for Innovation and Entrepreneurship of Vocational College Students Against the Background of "Internet Plus"}

First, good policy orientation provides the necessary entrepreneurial environment for innovation and entrepreneurship. Premier Li Keqiang first proposed the concept of "mass entrepreneurship and innovation" at the opening ceremony of the Davos Forum in 2014, and repeated it again and at the third session of the 12th National People's Congress in 2015, he once again put forward the idea and combined it with "Internet $+"$. Since then, the "mass entrepreneurship and innovation" policy has been widely implemented nationwide. With the continuous maturity of Internet technology, college students' entrepreneurial projects in the context of "Internet + " are becoming more and more abundant, and with the support of policies, more and more college students are engaged in the entrepreneurial wave [10]. Their role in promoting the development of China's national economy is also becoming more and more obvious.

Secondly, the increasingly close international exchanges also provide a good development opportunity for contemporary college students. In recent years, with the globalization of the economy and the continuous improvement of world integration, the exchanges between countries have become increasingly close. The implementation of many international strategies, such as the "G20 Summit" and the "Belt and Road Initiative", have brought significant improvement in China's international trade import and export. With the help of the Internet platform, transactions between countries have also become more convenient. The continuous improvement of China's comprehensive national strength and the increasing international trade, the platform of "Internet + " provides a greater opportunity for contemporary professional college students to innovate and start a business [11].

\section{Analysis of the Challenges of College Students' Innovation and Entrepreneurship Against the Background of "Internet Plus"}

Given the existing policies and the environment in China and foreign countries, vocational college students in China 
face both opportunities and challenges in innovation and entrepreneurship.

Among the challenges faced by vocational college students in innovation and entrepreneurship, the first is the difficulty of regional industrial transformation. In terms of China's current industrial development, many cities have already achieved industrial transformation. However, such cities are only limited to the southeastern coastal areas. The northwestern inland still bear many obstacles in the transformation of industrial structure. With Shaanxi Province in the northwestern region as an example, its industrial structure is dominated by the primary industry and the secondary industry, among which most are extensive economies. Although the local government has formulated corresponding measures to boost industrial transformation under the new normal [12], it can be seen from the current development level that the transformation fails to meet the expected results. Therefore, vocational college students engaging into innovation and entrepreneurship in such areas, they are shackled by the irrationality of the industrial structure and the resistance to transformation, making college students' innovation and entrepreneurship in the context of "Internet + " face greater challenges.

Secondly, there are major deficiencies in the core value of the product. As for current innovation and entrepreneurship of vocational college students in China, a good environment is provided in both China and foreign countries. However, their innovation and entrepreneurship projects are mainly dominated by product trading with low cost, low yield and low core value. Despite the good platform provided by "Internet + " technology, such products are prone to encounter poor sales because of the lack of core value of service or products, which will restrict the development of entrepreneurial enterprises to a large extent. Lack of core value of products is a great challenge faced by vocational colleges in the process of innovation and entrepreneurship.

Finally, the market is unevenly distributed. The so-called uneven market distribution refers to the distribution of entire market against the influence of the "Internet + " background is not particularly uniform. As far as the current development status of China is concerned, the uneven distribution of the market is mainly reflected in the following aspects. First of all, the market is geographically uneven distributed. The main market of China's "Internet + " related technologies is still distributed in the southeast coast and overseas markets. As for the inland areas of the northwest, it is mainly dominated by supply market, and there is no independent market operation system in the demand market, which makes college students face many challenges in the process of innovation and entrepreneurship. Secondly, the market of consumers is not balanced. Among the Chinese consumer group, most consumers of modern Internet and its products are youth population, and there are few middle-aged and elderly people. In addition, the lack corresponding market experience has posed challenges for college students in the process of innovation and entrepreneurship.
IV. ANALYSIS OF COUNTERMEASURES FOR COLLEGE STUDENTS' INNOVATION AND ENTREPRENEURSHIP AGAINST THE BACKGROUND OF "INTERNET PLUS"

\section{A. Continuously Improving the Comprehensive Quality of Vocational College Students' Entrepreneurship}

To continuously improve innovation and entrepreneurship ability of current vocational college students in the context of "Internet + ", the priority is that vocational colleges should continuously improve the comprehensive quality of vocational college students innovation and entrepreneurship through corresponding education. In this process, the relevant entrepreneurial instructors in vocational colleges should first actively guide students in combination with the actual situation of students, and help students choose reasonable entrepreneurial goals. Second, vocational college students should pay close attention to all fields of Internet before starting a business and maintain high sensitivity. They should implement suitable entrepreneurial project in a timely manner once they find it. [13] Finally, when choosing the entrepreneurial goal, the entrepreneurial instructor and the student should choose entrepreneurial goals based on the hobbies and practical ideas of student. Only in this way can students' innovation and entrepreneurship level be achieved effectively.

\section{B. Developing a Corresponding Talent Cultivation Plan}

At the present stage, most of the talent training plans of vocational colleges in China focus on cultivating students' vocational skills and professional qualities, but there are no corresponding plans and methods for students' innovation and entrepreneurship. As a result, many vocational college students have obvious disadvantages in the process of innovation and entrepreneurship. Therefore, in the process of vocational college education, relevant employment guidance departments should formulate corresponding talent training plans and improve and innovate the innovation and entrepreneurial education methods and means based on the actual situation of students. In this process, professional employment instructors can be used to teach students the basic courses of innovation and entrepreneurship in vocational colleges, while for practical courses, entrepreneurs from enterprises could be employed externally to guide students' entrepreneurship [14]. With this as basis, it's possible to combine entrepreneurial theory with practice to continuously improve students' perception of "Internet+" technology, which has a very positive role in enhancing their ability to innovate and start their own businesses.

\section{Providing Necessary Policy Support}

Compared with social personnel, vocational college students can distinguish themselves in terms of theoretical knowledge and professional skills. However, there are major deficiencies in the smooth development of entrepreneurial work, such as poor freedom of entrepreneurial time arrangement or lack of funds. In order to fundamentally solve the problems existing in the process of college students' innovation and entrepreneurship, one of the most important ways is to give the vocational college students the necessary policy support [14]. For example, to improve the flexibility of college students to choose courses, so that they 
can allocate their own time reasonably; or to provide a preferential loan policy to alleviate the shortage of students' funds.

\section{Emancipating the Mind and Changing the Perception of Entrepreneurship}

Due to the lack of cognition or great deviation of entrepreneurship of college students in many vocational colleges, most of them choose their own career in the process of career choice and entrepreneurship. In this way, the overall level of innovation and entrepreneurship of college students will be reduced to a large extent. Based on this situation, vocational colleges can liberate students' thoughts and enhance students' awareness of entrepreneurship by adding corresponding entrepreneurial lectures in the daily teaching process of college students, and encouraging college students to practice innovation and entrepreneurship during school days or during the holidays, which can improve the overall level of innovation and entrepreneurship of vocational college students in China.

\section{E. Making Fine Division and Improving the Rationality and Scientificity of Entrepreneurship}

The so-called fine division actually refers to the fine division of institutions and market [16]. First: the division of vocational colleges. There are many vocational colleges of diverse types in China, In general, vocational colleges are mainly divided into comprehensive vocational colleges and specialized comprehensive colleges. The government should give full play to its leading function and build a good entrepreneurial platform for colleges and universities when classifying vocational colleges. What's more, it should also encourage the division and cooperation of institutions of different types within the process to continuously improve innovation and entrepreneurship; secondly, the fine division of the market. In recent years, China's Internet has become more and more mature and various commercial activities have blossomed. Based on this situation, the government and institutions should provide a comprehensive and fast information platform for college students in the process of innovation and entrepreneurship, so that students can fully understood the market, which can not only effectively avoid case imitation, but also give full play to students' innovation ability to a large extent.

\section{F. Combining Production, Study and Research, and Making Improvement Continuously}

In the era of "Internet $+"$, although there are more and more entrepreneurial projects and platforms for college students, it is necessary to complete specific entrepreneurial goals on the premise of multi-party support. This process requires efforts from universities, enterprises and students, as well as government agencies and social organizations. Only in this way can the overall improvement of students' innovation and entrepreneurship be achieved. In order to realize the multi-party participation in the process of innovation and entrepreneurship of college students, one of the most important tasks is to continuously promote the combination of production, study and research, and to continuously improve the innovation and entrepreneurial ability of contemporary college students, which plays a positive role in realizing the improvement of China's modernization level. There are many forms of integration of production, study and research in China and foreign countries, such as self-study cooperation between schools and enterprises, research centers for schools and enterprises, construction of science and technology parks, establishment of related foundations, and all-round cooperation between universities and local regions. In the actual application process, universities, enterprises and governments should choose the most effective combination according to their respective situations. For colleges and universities in China, it's possible to realize the combination of production, study and research by establishing university science park. The university science park is an important place to combine teaching, scientific research and production. The university technology innovation base, high-tech industry incubation base and innovation and entrepreneurial talent cultivation base within the park can improve the combination of production, study and research in China to a large extent, which has a profound impact on improving the ability of college students to innovate and start business and improving their level against the background of "Internet +".

\section{CONCLUSION}

In summary, with the advent of the "Internet + " era and the implementation of the "Mass entrepreneurship and innovation" policy, China's national economy has also entered a new historical period, during which time entrepreneurship has also become an important factor for improving the long-term effective development of China's national economy. As a major force for entrepreneurship in China, vocational college students face many opportunities and challenges in the new era. Contemporary vocational college students need to emancipate their minds, change their cognition of entrepreneurship, and continuously improve the comprehensive development of vocational college students. As for vocational college, in the process of entrepreneurship education, relevant employment guidance departments should formulate corresponding talent training plans, and combine the actual situation of students to improve and innovate innovation and entrepreneurial education methods and educational methods; the government should give full play to its leading role, build a good entrepreneurial platform for colleges and universities, and encourage cooperation between institutions of different types, realize the combination of production, study and research in this process, provide necessary policy support, continuously improve innovation and entrepreneurship, and make effective exploration of China's entrepreneurial approach with this as basis, which will have a far-reaching impact on the long-term effective development of China's national economy.

\section{REFERENCES}

[1] Liu Fang, Yang Xingquan, Tu Haibo, Zhang Yongzhi, Hao Chuanyong, Zhao Changsong. Exploration and Research on the Training Mode of Innovative and Entrepreneurial Talents in Applied Private Undergraduate Colleges Based on the Background of "Internet Plus" [J]. Science \& Technology Industry Parks, 2018 (12): 67-68. (in Chinese) 
[2] Zhang Huiyan. Research on the Innovation and Entrepreneurship of Higher Vocational Colleges Under the Environment of "Internet Plus" [J]. Modern Marketing (Business Edition), 2018 (06): 190-191. (in Chinese)

[3] Zhang Lele. Exploration on the Cultivation Path of College Students' Innovation and Entrepreneurship Ability Under the Environment of "Internet Plus" [J]. Software Guide (Education Technology), 2018,17(05):20-22. (in Chinese)

[4] Wu Shangzhuo. Analysis of the Opportunities and Challenges of College Students' Innovation and Entrepreneurship Education Under the Background of "Internet Plus" [J]. Human Resources Management, 2018(05):288-289. (in Chinese)

[5] Xie Yajun. Analysis on the Cultivation of College Students' Innovation and Entrepreneurship Under the Background of "Internet Plus" [J]. Knowledge Economy,2018(09):150-151. (in Chinese)

[6] Chen Huifang. Countermeasures for College Students' Innovation and Entrepreneurship Education Under the Background of "Internet Plus" [J]. Journal of College Advisors, 2018, 10(02): 69-72. (in Chinese)

[7] Zhang Linan. Research on the Countermeasures of College Students' Innovation and Entrepreneurship Development Under the Perspective of "Internet Plus" [J]. Journal of Hubei Correspondence University, 2018,31(08):6-7. (in Chinese)

[8] Sun Yudi, Pei Yong. Exploration of Innovation and Entrepreneurship Education in Higher Vocational Colleges Under the Vision of "Internet Plus" [J]. Journal of Innovation and Enterprise Education, 2018, 9(02): 117-119. (in Chinese)

[9] Zhang Chao. Research on the Cultivation Path of Innovation and Entrepreneurship Based on "Internet Plus" Under the New Normal [J]. Business Culture, 2018(12): 92-93. (in Chinese)

[10] Liang Jun. Research on College Students' Entrepreneurial Model and Entrepreneurial Policy Under the Background of "Internet Plus" [J]. China Newspaper Industry, 2018(06):99-100. (in Chinese)

[11] Chu Haiping. The Basic Thinking and Realization Path of "Internet Plu Innovation and Entrepreneurship Education" [J]. Modern Education Science, 2018 (03): 117-120+131. (in Chinese) 